\title{
PENGELOLAAN PERTEMUAN PELANGGAN DI BNI SYARIAH KCP CILEDUG
}

\author{
Saridawati \\ Universitas Bina Sarana Informatika \\ Email: .sti@bsi.ac.id
}

\begin{tabular}{l}
\hline \multicolumn{1}{c}{ Artikel info } \\
\hline Artikel history: \\
Diterima: 06 November \\
2020 \\
Diterima dalam bentuk \\
revisi: 14 November 2020 \\
Diterima dalam bentuk \\
revisi: 20 November 2020
\end{tabular}

revisi: 20 November 2020

\section{Keywords:}

Management, meetings, customers
Abstract: The purpose of this study is to determine the process of managing customer meetings, to find out how BNI Syariah $K C P$ Ciledug retains customers, to determine customer expectations for BNI Syariah KCP Ciledug, to find out the obstacles faced by BNI Syariah KCP Ciledug To find out the products offered at BNI Syariah KCP Ciledug. This research method is a qualitative research. Qualitative research is a research procedure that produces descriptive data in the form of written or spoken words from people and observable behavior. A qualitative approach is a process of research and understanding based on methodology that investigates social phenomena and human problems. Results of Customer Meeting Management, namely a planning process with face-to-face communication media with several consumers or service users to ask for some information needed by consumers. Companies realize that consumers, especially customers, are more concerned with service than the value of a product. The investment value of a service by managing customer meetings can provide long-term benefits for BNI Syariah, so service quality is a top priority for BNI Syariah.

Abstrak: Tujuan penelitian ini adalah Untuk mengetahui proses pengelolaan pertemuan pelanggan,Untuk mengetahui cara BNI Syariah KCP Ciledug dalam mempertahankan pelanggan,Untuk mengetahui harapan pelanggan terhadap BNI Syariah KCP Ciledug,Untuk mengetahui hambatan yang dihadapi BNI Syariah KCP Ciledug. Untuk mengetahui produk yang ditwarkan di BNI Syariah KCP Ciledug. Metode Penelitian ini merupakan penelitian kualitatif. Penelitian kualitatif adalah prosedur penelitian yang menghasilkan data deskriptif berupa kata-kata tertulis atau lisan dari orang-orang dan perilaku yang dapat diamati. Pendekatan kualitatif adalah suatu proses penelitian dan pemahaman yang berdasarkan pada metodelogi yang menyelidiki suatu fenomena social danmasalah manusia. Hasil Pengelolaan Pertemuan Pelanggan yaitu suatu proses perencanaan dengan media komunikasi secara tatap muka dengan beberapa konsumen atau pengguna 


\section{Kata Kunci:}

Pengelolaan, pertemuan, pelanggan jasa untuk menanyakan beberapa informasi yang dibutuhkan oleh konsumen. Perusahaan sadar, konsumen terlebih pelanggan saat ini lebih mementingkan pelayanan daripada nilai suatu produk. Nilai investasi dari sebuah pelayanan dengan mengelola pertemuan pelanggan dapat memberikan keuntungan jangka panjang bagi BNI Syariah, maka kualitas pelayanan pun menjadi prioritas utama bagi BNI Syariah.

Koresponden author:

Email: .sti@bsi.ac.idartikel dengan akses terbuka dibawah lisensi

CC BY SA 2020

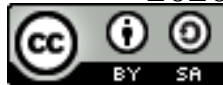

\section{Pendahuluan}

Pemasaran merupakan bagian dari manajeman perusahaan dan juga salah satu faktor yang sangat penting, karena pemasaran akan mempengaruhi secara langsung terhadap kelancaran maupun keberhasilan perusahaan dalam mencapai tujuannya. Penting bagi perusahaan untuk mengatahui strategi pemasaran yang tepat dan sesuai untuk produk yang akan dijual di pasaran. Dengan strategi pemasaran tepat dan sesuai maka produk akan mudah diterima calon konsumen sehingga calon konsumen membeli produk yang akan dijual. Selain strategi pemasaran perusahaan perlu mengetahui posisi produk yang dijual. Posisi disini menujukkan perbandingan mengenai pangsa pasar dan pertumbuhan pasar dari para pesaingan produk yang sejenis dari perusahaan lain (Rini, 2013).

Keberhasilan perusahaan dalam memasarkan produk-produk sangat tergantung pada kiat-kiat dan strategi pemasaran yang dilakukan karena dengan penerapan strategi pemasaran yang tepat, perusahaan dapat menciptakan dan memelihara serta mengembangkan permintaan konsumen secara menyakinkan dan berkesinambungan. Apabila omset penjualan mengalami peningkatan yang lambat, maka harus dianalisis apakah haltersebut disebabkan oleh kurang efektifnya strategi pemasaran yang dilakukan atau mungkin di pengaruhi oleh selera dan perilaku konsumen yang sudah berubah (Setiadi \& SE, 2015).

Setiap perusahaan baik itu industri manufaktur maupun industri jasa dalam memasarkan produknya mempunyai tujuan. Secara umum tujuan perusahaan adalah mencapai dan meningkatkan keuntungan melalui volume penjualan yang menguntungkan, artinya laba tingkat kepuasan yang lebih besar kepada konsumen serta dapat memperkuat kondisi perekonomian secara keseluruhan itu dapat diperoleh dengan melalui pemuasan konsumen. Dengan laba ini perusahaan dapat tumbuh dan berkembang dapat menggunakan kemampuan yang lebih besar, dapat memberikan.

Dalam menjalankan usahanya, pemilik usaha harus dapat menentukan strategi apa yang harus dipakai agar dapat menciptakan kepuasan dari pelanggan (Nurcholifah, 2014). Karena kepuasan pelanggan akan dapat terbentuk jika pemasar dapat memberikan pelayanan yang berkualitas. Kualitas pelayanan memiliki hubungan yang erat dengan kepuasan konsumen. Kualitas memberikan suatu dorongan kepada konsumen untuk menjalin ikatan hubungan yang kuat dengan perusahaan (Listyawati, 2014). 


\section{Metode Penelitian}

Penelitian ini merupakan penelitian kualitatif. Penelitian kualitatif adalah prosedur penelitian yang menghasilkan data deskriptif berupa kata-kata tertulis atau lisan dari orangorang dan perilaku yang dapat diamati (Moleong, 2007). Metode penelitan kualitatif adalah metode penelitian yang digunakan untuk meneliti dalam kondisi yang alamiah (sebagai lawannya adalah eksperimen) dimana peneliti adalah sebagai instrument kunci, teknik pengumpulan data dilakukan secara trianggulasi (gabungan), analisis data yang bersifat induktif, dan hasil penelitian kualitatif lebih menekankan makna daripada generalisasi (Sugiono, 2009).

Pendekatan kualitatif adalah suatu proses penelitian dan pemahaman yang berdasarkan pada metodelogi yang menyelidiki suatu fenomena social dan masalah manusia. Padapendekatan ini, peneliti membuat suatu gambaran kompleks, meneliti kata-kata, laporan terinci dari pandangan responden, dan studi pada situasi yang alami (Creswell, 1998) Book dan Taylor , mengemukakan bahwa metodelogi kualitatif merupakan prosedur penelitian yang menghasilkan data deskriptif berupa kata-kata tertulis maupun lisan dari orang-orang dan perilaku yang diamati. Penelitian ini menggunakan Metode Survei. Metode Survei adalah suatu metode yang digunakan untuk mendapatkan hasil riset dalam bentuk pendapat yang berinteraksi langsung dengan objek yang diamati (Suyanto, 2015). Tujuan utama dari metode ini adalah mendapatkan gambaran umum.

\section{Hasil dan Pembahasan}

\section{Sejarah dan Profil Singkat Bank BNI Syariah}

Sejak awal didirikan pada tanggal 5 juli 1946, sebagai Bank pertama yang secara resmi dimiliki Negara RI, BNI merupakan pelopor terciptanya berbagai produk dan layanan jasa perbankan. BNI terus memperlus perannya,tidak hanya terbatas sebagai bank pembangunan,tetapi juga ikut melayani kebutuhan transaksi perbankan masyarakat umum dengan berbagai segmentasinya,mulai dari Bank Terapung, Bank Sarinah (bank khusus perempuan) sampai dengan Bank Bocah khusus anak-anak. Seiring dengan pertambahan usianya yang memasuki 67 tahun, BNI tetap kokoh berdiri dan siap bersaingdi industri perbankan yang semakin kompetitif. Dengan semangat "'Tak Henti Berkarya" BNI akan terus berinovasi dan berkreasi, tidak hanya terbatas pada penciptaan produkdan layanan perbankan,bahkan lebih dari itu BNI juga bertekad untuk menciptakan "value" pada setiap karyanya (Herawati, 2018).

Berdiri sejak 1946, BNI yang dahulu dikenal sebagai Bank Negara Indonesia, merupakan Bank pertama yang didirikan dan dimiliki oleh Pemerintah Indonesia(Abdullah, 2013). Sejalan dengan keputusan penggunaan tahun pendirian sebagai bagian dari identitas perusahaan, nama Bank Negara Indonesia 1946 resmi digunakan mulai akhir tahun 1968. Perubahan ini menjadikan Bank Negara Indonesia lebih dikenal sebagai "BNI 46" dan ditetapkan bersamaan dengan perubahan identitas perusahaan tahun 1988. Dari tahun ke tahun BNI selalu menunjukkan kekuatannya dalamindustri perbankan dan kepercayaan masyarakat pun terbangun dan memilih Bank Indonesia sebagai pilihan tempat penyimpanan segala alat kekayaan yang terpercaya. Permintaan akan perbankan yang sesuai dengan prinsip syariah pun mulai bermunculan 
yang pada akhirnya BNI membuka layanan perbankan yang sesuai dengan prinsip syariah dengan konsep dual system banking, yakni menyediakan layanan perbankan umum dan syariah sekaligus.

Hal ini sesuai dengan UU No. 10 Tahun 1998 yang memungkinkan bank-bank umum untuk membuka layanan syariah, diawali dengan pembentukan Tim Bank Syariah di Tahun 1999, Bank Indonesia kemudian mengeluarkan izin prinsip dan usaha untuk beroperasinya unit usaha syariah BNI. Setelah itu BNI Syariah menerapkan strategi pengembangan jaringan cabang, syariah sebagai berikut :

a. Tepatnya pada tanggal 29 April 2000 BNI Syariah membuka 5 kantor cabang syariah sekaligus di kota-kota potensial, yakni: Yogyakarta, Malang, Pekalongan, Jepang, dan Banjarmasin.

b. Tahun 2001 BNI Syariah kembali membuka 5 kantor cabang syariah yang difokuskan ke kota-kota besar di Indonesia, yakni : Jakarta (2 cabang), Bandung, Makassar, dan Padang.

c. Seiring dengan perkembangan bisnis dan banyaknya permintaan masyarakat untuk layanan perbankan syariah, tahun 2000 lalu BNI Syariah membuka dua kantor cabang Syariah baru di Medan dan Palembang.

d. Di awal tahun 2003, dengan pertimbangan lood bisnis yang semakin mengkat sehingga untuk meningkatkan pelayanan kepada masyarakat, BNI Syariah melakukan relokasi kantor cabang syariah dari Jepang ke Semarang. Sedangkat untuk melayani masyarakat kota Jepara, BNI Syariah membuka kantor Cabang Cabang Pembantu Syariah Jepara.

e. Pada bulan Agustus dan September 2004, BNI Syariah membuka layanan BNI Syariah Prima di Jakarta dan Surabaya. Layanan ini diperuntukkan untuk individu yang membutuhkan layanan perbankan yang lebih personal dalam suasana yang nyaman. Dari awal beroperasi hingga kini, BNI Syariah menunjukkan pertumbuhan yang signifikan. Disamping itu komitmen Pemerintah terhadap perkembangan perbankan syariah semakin kuat dan kesadaran terhadap keunggulan produk perbankan syariah juga semakin meningkat.

2 Struktur Organisasi

4.2.1 Susunan Organisasi

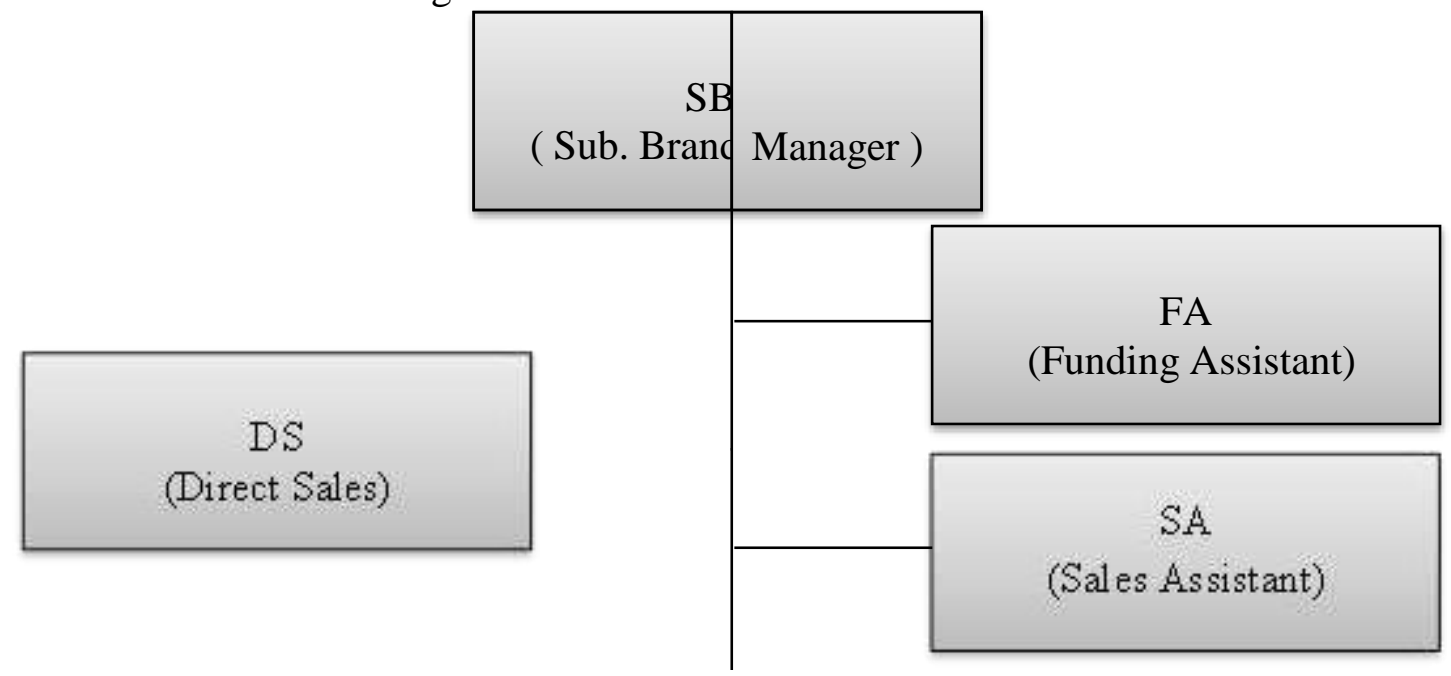




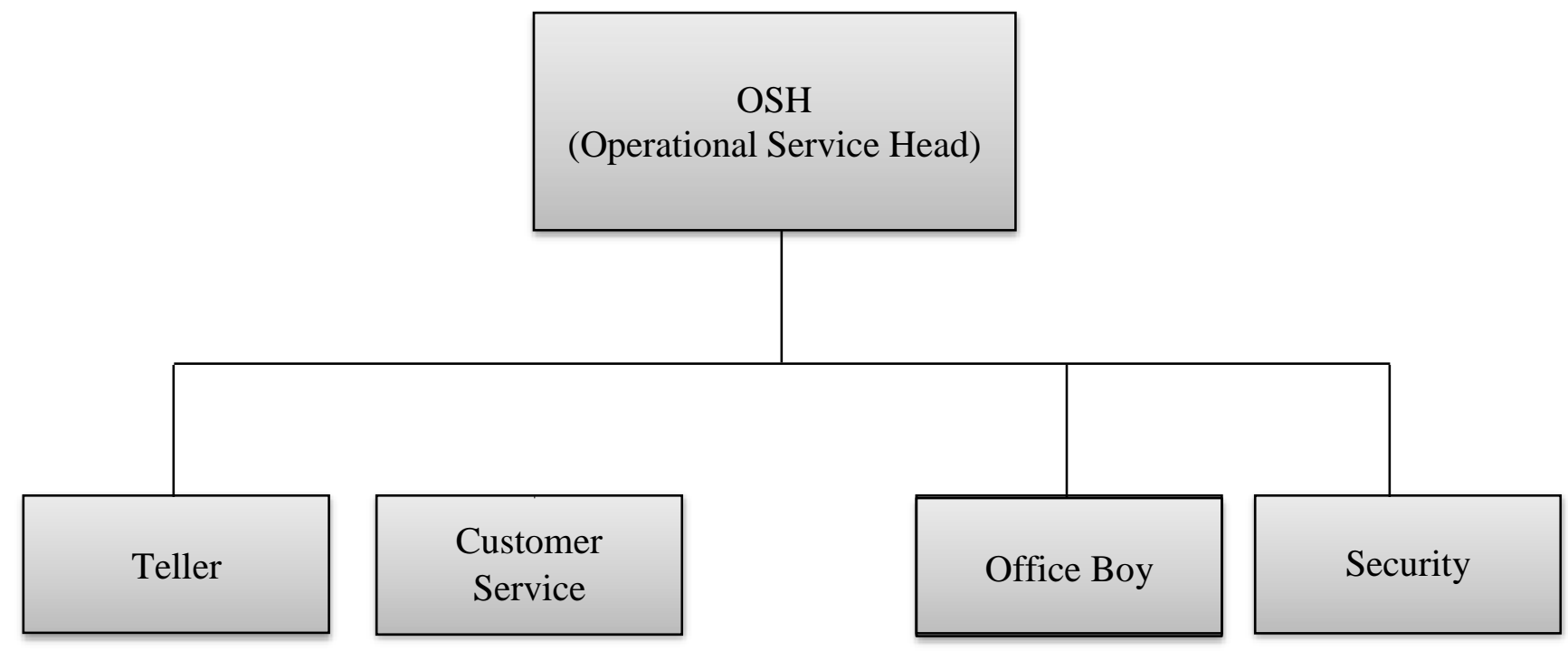

a. Tata Kerja Susunan Organisasi

\section{Sub Branch Manager}

Mengelola kegiatan operasional bank baik dari luar perusahaan maupun dari dalam perusahaan itu sendiri dan yang mengatur keseluruhan bisnis.

\section{Operational Service Head (OSH)}

Mengkoordinir dan memonitor tugas serta bertanggung jawab melayani sesuai SOP yang telah disepakati dengan mengadakan briefing ataupun controlling area. Melaksanakan pengawasan langsung operasional secara keseluruhan dengan controlling rutin.

\section{Funding Assistant (FA)}

Membantu melayani produk bisnis tabungan seperti Direct Message dan Internet Banking, dan menanggani pembukaan rekening Nasabah-nasabah perusahaan.

\section{Direct Sales (DS)}

Melakukkan penjualan produk langsung pada konsumen, sesuai dengan target pasar yang akan dituju.

\section{Sales Assistant}

Membantu melayani pembukaan rekening tabungan perencanaan rumah.

\section{Customer Service.}

Menanggani keluhan-keluhan nasabah dalam pembukaan rekening dan Membantu pimpinan cabang dalam mengendalikan manajemen cabang.

\section{Teller}

Melakukan transaksi nasabah secara tunai maupun non tunai.

\section{Security}

Melakukan pengamanan asset ditempat bekerta sertamembantu beberapa aturan perusahaan yang berhubungan dengan keaamanan kenyamanan Nasabah.

\section{Office Boy ( $O B$ )}

Membantu dan melaksanakan tugas-tugas yang diberikan oleh staff umum, dan bertanggung jawab atas kebersihan dan kerapihan kantor dan sekitar.

\section{Jenis Produk BNI Syariah}
a. Baitullah BNI iB Hasanah 
Tabugan ini merupakan tabungan syariah yang dapat dibuka oleh siapa saja, akad yang digunakan ada 2 yaitu Mudharabah dan Wadiah yang memberi kemudahan kepada nasabah dalam menabung menggunakan mata uang rupiah dan BNI Baitullah IB Hasanah dilengkapi dengan Kartu Haji \& Umroh Indonesia yang bisa digunakan juga sebagai sarana pembayaran Haji, untuk mendapatkan kepastian porsi berangkat menunaikan Ibadah Haji sebagai kartu ATM/Debit yang bisa digunakan di Tanah Suci dan Tanah Air, tabungan ini mendapatkan fasilitas perbankan berupa buku tabungan, kartu ATM dan fitur transaksi ATM, SMS Banking, Internet Banking, dan Mobile Banking sehingga mempermudah melakukantransaksi kapanpun.

b. Syariah BNI iB Hasanah

Tabungan ini merupakan tabungan syariah yang dapat dibuka oleh siapa saja, akad yang digunakan ada 2 yaitu Mudharabah dan Wadiah yang memberikan kemudahan kepada nasabah dalam menabung menggunakan mata uang Rupiah,tabungan ini akan mendapatkan berbagai fasilitas buku tabungan, transaksi eBangking seperti Internet Bangking, SMS Bangking, Mobile Bangking dan lain-lain. BNI iB Hasanah dilengkapi dengan Hasanah Debit Silver sebagai kartu ATM/Debit yang dapat digunakan untuk transaksi di merchant MasterCard seluruh dunia.

c. Bisnis BNI iB Hasanah

Tabungan dengan informasi transaksi dan mutasi rekening yang lebih detail, bagi hasil yang kompetitif, serta berbagai fasilitas transaksi e-Banking. BNI Bisnis iB Hasanah dilengkapi dengan Hasanah Debit Gold. BNI Bisnis iB Hasanah tersedia dalam akad Wadiah dan Mudharabah. Bentuk investasi dana yang dikelola berdasarkan prinsip syariah dengan akad Mudharabah yang dilengkapi dengan detail mutasi debet dan kredit pada buku tabungan dalam mata uang Rupiah dan bagi hasil yang lebih kompetitif untuk segmen usaha kecil guna memenuhi kebutuhan investasi aset produktif seperti rumah kost.

d. Jenis Transaksi BNI Syariah

\section{BNI Syariah memiliki 2 jenis transaksi terdiri atas:}

A. Transaksi Perorangan

Transaksional

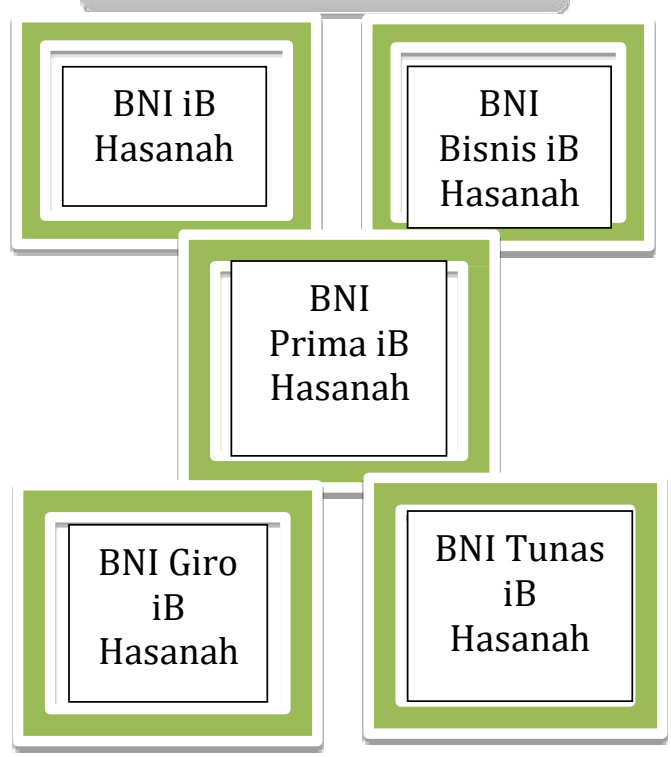

B. Transaksi Non Perorangan

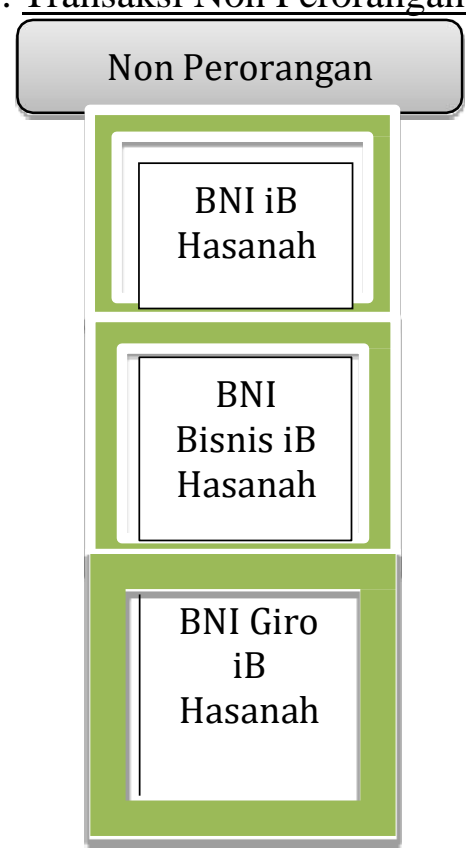



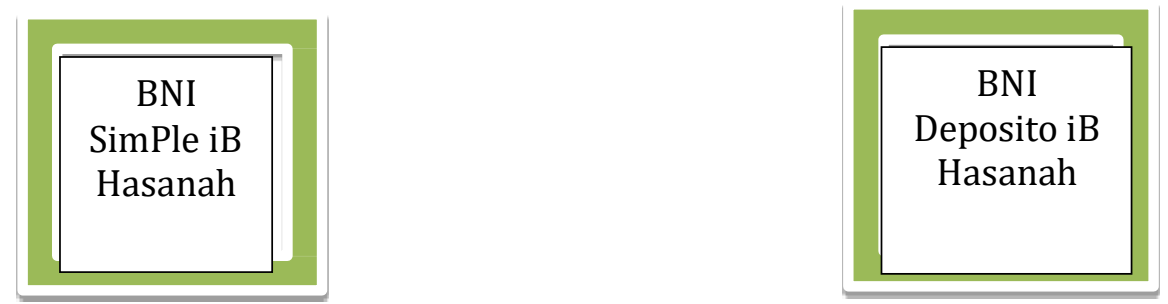

\section{Hasil Riset}

\section{Perencanaan Pertemuan Pelanggan}

Perencanaan pertemuan pelanggan di BNI Syariah KCP Ciledug memiliki 4 cara, yaitu:

a. Walk In Customer

Pengguna jasa BPR/BPRS yang tidak memiliki rekening pada BPR/BPRS tersebut, tidak termasuk pihak yang mendapatkan perintah atau penugaasan dari nasabah, untuk melakukan transaksi atas kepentingan nasabah tersebut seperti pembukaan rekening langsung dilakukan di kantor BNI Syariah KCP Ciledug

b. OT (Open Table)

Suatu kegiatan yang dilakukan untuk memperlihatkan produk tertentu kepda nasabah yang bersifat sementara, baik direncanakan maupun tidak direncanakan dengan melakukan promosi melalui surat ataupun telepon.

c. Perjanjian

Membuat persetujuan dengan nasabah terlebih dahulu yang dibuat oleh dua pihak atau lebih, secara tertulis maupun lisan.

\section{d. Survey}

Melakukan survey secara langsung kepada nasabah, dengan membuat perjanjian terlebih dahulu kepada pihak bank maupun nasabah.

\section{Cara Mempertahankan Pelanggan}

Ada beberapa cara yang dilakukan BNI Syariah KCP Ciledug untuk mempertahankan pelanggannya, yaitu:

a. Meningkatkan pelayanan prima dengan selalu mengucapkan salam dan memakai tagline kepada nasabah.

b. Bersikap dan memberi kesan profesional kepada semua pelanggan atau nasabah.

c. Menawarkan deposito dengan sistem bagi hasil.

d. Memberi reward untuk setoran awal diatas Rp. 25.000.000.

e. Memberikan kemudahan pelayanan kepada Nasabah melalui media online dalam hal keluhan, kritik maupun saran.

f. Memberikan kemudahan transaksi kepada Nasabah melalui Website.

\section{Harapan - Harapan Pelanggan}

1. Pembeli Membeli Pelayanan bukan Produk

Pelanggan itu tidak membeli produk yang kita tawarkan, tetapi membeli pelayanan yang kita berikan. Kalau pelayanan kita baik, ramah, penuh perhatian dan dapat memenuhi kebutuhan pelanggan pada saat mereka datang dan melihat, maka dari melihat kemudian mereka mencoba, meneliti, sampai akhirnya memutuskan untuk membeli. 


\section{Harapan - harapan Lain Pelanggan}

a. Setiap pelanggan mengharapkan pelayanan yang baik.

b. Pelanggan mempunyai hak akan informasi yang jujur dan benar tentang produk yang akan dibelinya.

c. Pelanggan mengharapkan pelayanan purna jual (after sales service) ataupelayanan setelah penjualan.

d. Pelanggan mengharapkan potongan harga atas barang yang dibelinya.

e. Pelanggan mengharapkan kelayakan harga atas barang yang dibelinya.

4. Hambatan yang dihadapi BNI Syariah KCP Ciledug

Hambatan yang dihadapi BNI Syariah ada beberpa diantaranya:

Kurangnya pegawai yang ahli dalam memasarkan produk BNI Syariah.

Faktor yang menjadi penghambat adalah kurangnya SDM yang luwes, tidak tepat dan cepat dalam melayani nasabah sehingga nasabah merasa tidak terlayani dengan baik. Persaingan antar bank konvensional maupun bank syariah.

Kurangnya persediaan kantor BNI Syariah di beberapa wilayah, minimnya jumlah kantor- kantor cabang yang tersebar, membuat para nasabah masih sulit untuk bertransaksi.

\section{Kesimpulan}

Berdasarkan uraian diatas dapat kita ambil kesimpulan bahwa meningkatnyapersaingan dalam dunia perbankan membuat perusahaan beralih strategi, maka dari itu sangat penting untuk BNI Syariah mempertahankan kualitas pelayanannya dengan mengatur Pengelolaan Pertemuan Pelanggan dengan begitu konsumen akan tetap menggunakan jasa yang mereka terapkan. Pengelolaan Pertemuan Pelanggan yaitu suatu proses perencanaan dengan media komunikasi secara tatap muka dengan beberapa konsumen atau pengguna jasa untuk menanyakan beberapa informasi yang dibutuhkan oleh konsumen. Perusahaan sadar, konsumen terlebih pelanggan saat ini lebih mementingkan pelayanan daripada nilai suatu produk. Nilai investasi dari sebuah pelayanan dengan mengelola pertemuan pelanggan dapat memberikan keuntungan jangka panjang bagi BNI Syariah, maka kualitas pelayanan pun menjadi prioritas utama bagi BNI Syariah. 
Saridawati

\section{Bibliografi}

Abdullah, Y. (2013). Pengungkapan Corporate Social Responsibility (CSR) Pada Bank Konvensional Di Indonesia. Universitas Muhammadiyah Surakarta.

Creswell. (1998). Laser induced nuclear reactions. AIP Conference Proceedings, 454(1), 229-234.

Herawati, I. (2018). Pengaruh Cost Of Fund Giro Dan Deposito Terhadap Return On Assets (Roa) Pada Pt. Bank Negara Indonesia (Persero) Tbk. STIE Ekuitas.

Listyawati, I. H. (2014). Penerapan Total Quality Management (TQM) Sebagai Upaya

Membangun Kepuasan Pelanggan. Jurnal Bisnis, Manajemen, Dan Akuntansi, 2(2).

Moleong, L. J. (2007). Metode penelitian kualitatif. Bandung: Remaja Rosdakarya.

Nurcholifah, I. (2014). Strategi marketing mix dalam perspektif Syariah. Jurnal Khatulistiwa LP2M IAIN Pontianak, 4(1), 73-86.

Rini, E. S. (2013). Peran pengembangan produk dalam meningkatkan penjualan.

Setiadi, N. J., \& SE, M. M. (2015). Perilaku konsumen. Kencana.

Sugiono. (2009). penelitian kualitatif.

Suyanto, B. (2015). Metode Penelitian Sosial: Berbagai Alternatif Pendekatan. Prenada Media. 